\title{
Development of carbon microcoils (CMCs) and their future prospect
}

\section{陳 秀琴, 元島栖二*}

Xiuqin Chen and Seiji Motojima*

Carbon micro-coils (CMCs) with 3D-helical/spiral structures and coil diameters of $\mu \mathrm{m}$ orders were obtained by the metalcatalyzed pyrolysis of acetylene at $700 \sim 800{ }^{\circ} \mathrm{C}$. In this review, the preparation process, morphology, microstructure, properties, and some applications of CMCs are introduced and their future prospect is discussed. The as-grown CMCs have almost amorphous structure, but were graphitized by high temperature heat treatment with full preservation of the coiling morphology. The CMCs could effectively generate inductive electromotive force, inductive current and thus Joul's heat under the application of microwaves. The CMCs/elastic polymer composite elements showed high tactile/proximity sensing properties which are comparable to that of human skin. The CMCs are a possible candidate for electromagnetic wave absorbers, remote heating materials, visualization elements of microwaves, tactile/proximity sensor elements, micro-antenna, chiral catalysts, bio-activators or bio-deactivators, energy converters, etc.

KEYWORDS : Carbon microcoils, Vapor grown carbon fiber, Electromagnetic wave absorber, Tactile sensor, Bio-activator

\section{1. はじめに}

ナノテクノロジーを支えるナノ材料の中で, 最近フラーレン, ナ ノチューブ, ナノホーンなどの新炭素系材料が非常に注目され, 多くの研究者により精力的な研究が行われている。著者らは, 1989年に世界で初めて3D-ヘリカル／らせん状に巻いた窒化ケ イ素ファイバーの合成に成功した1)。さらに1990年にはカーボ ンマイクロコイル $(\mathrm{CMC})$ を再現性良く気相合成することにも成 功した2)。CMCは，コイル径が $\mu \mathrm{m} \sim \mathrm{nm}$ オーダーの3D-へリカ ル／らせん形態で非晶質という既存素材・材料には見られない 特異的構造をもち, マイクロ波領域の電磁波吸収材, マイクロ波 発熱材, 触覚・近接センサ素子, マイクロアンテナ, 電子線エミッ ター, ガンやケロイドの治療薬など, 幅広い応用が期待されてい る革新的新素材である。

本稿では, CMCの合成法, モルフォロジー, 微細構造, 特性およ び応用の現状を簡単に紹介し, その将来展望を行う。なお, CMCに 関する総説は, 本誌の 1992 [No.151]3) および1996 [No.174]4)に も掲載されたので, 1996年以降の発展を紹介する。なお, 特集 「へリカル／らせん構造物質・材料とその応用」5) および最近の レビュー6)-9）も参照されたい。

\section{CMCの合成法・モルフォロジー・微細構造}

\section{1 合成法}

$\mathrm{CMC}$ は, 微量のイオウ不純物を含むアセチレンを, $\mathrm{Ni}$ 微粉末な どの金属触媒存在下, $700 \sim 800{ }^{\circ} \mathrm{C} て ゙$ 熱分解することにより合成 できる。CMCは原料ガス導入方向に向かって基板上にほぼ垂直 に, 約 $60 \mathrm{rpm}$ の速度で回転してコイル形状を作りながら成長す る。高温反応では，一般に交流電気ヒーター加熱を用いるが, こ の場合反応場には強力な変動電磁場が発生する。反応場に変動 電磁場, 静磁場, バイアス電場, プラズマ場, あるいは超音波場など の協奏増幅反応場エネルギーを照射すると,アセチレンの分解反 応, $\mathrm{CH}_{3}+$ イオンの生成, 触媒粒子の活性化, $\mathrm{CMC}$ の成長パターン やコイル成長速度などが大きな影響を受け, したがってコイル形態 やコイル収量が変化する。例えば, 通常の ACヒーター加熱で得 られる沉用 CMCは，コイルを形成しているカーボンファイバー の断面が長方形〜リボン状の “扁平コイル”であるが, 成長初期 や電磁波を発生しないバーナー加熱を用いるとファイバー断面 が円形〜楕円形の “円形コイル”が得られる。CMCは応用面で はその伸縮性が重要であり，その点では後者のほうが有利である。 しかし, コイル収量の点ではACヒーターを用いたほうが高く, こ の場合原料アセチレンに対するコイル収率は $15 ２ 0 \%$ ある。

2.2 モルフォロジー

Fig.1に, 代表的なCMCのSEM写真を示す。CMCは,一般に

* Corresponding Author, E-mail: motojima@apchem.gifu-u.ac.jp (平成 19 年7月31日受理, 平成 19 年8月28日採択) 岐皁大学工学部：=501-1193 岐阜市柳戸1-1

Faculty of Engineering, Gifu University : Gifu 501-1193, Japan 


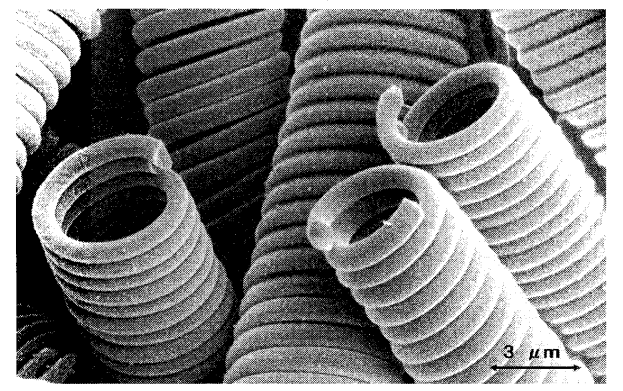

Fig.1 Representative double-helix CMCs.

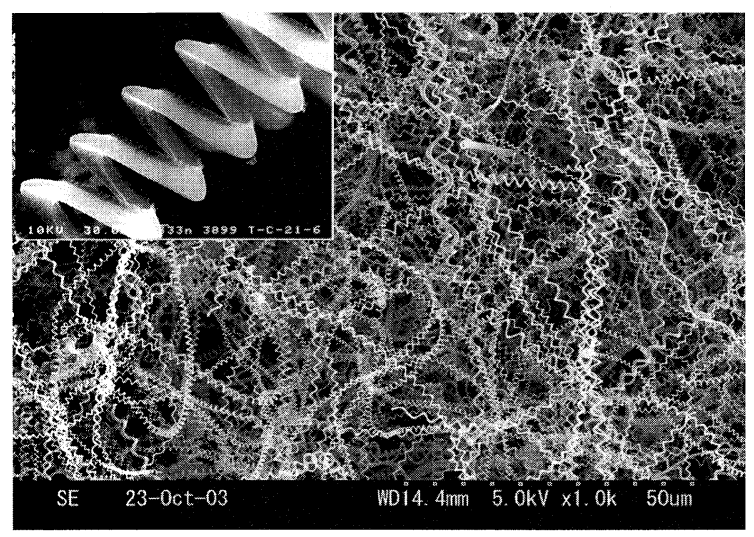

Fig.2 Representative single-helix CMCs.

2本のカーボンファイバーが一定のコイル径とコイルピッチで規 則的に同じ方向に巻いており, DNA と同様な二重らせん構造を している。1本のコイル中では, ファイバー径, コイル径およびコ イルピッチはほぼ一定であり, また巻き方向は途中で変化せず一定 (右巻きあるいは左巻き)である。右巻き $\mathrm{CMC}$ と左巻き $\mathrm{CMC}$ の 本数は, 触媒の種類や反応条件に依存せずほぼ同数である。一般 に, CMCのコイル径は $1 \sim 10 \mu \mathrm{m}$, コイルを形成しているカーボ ンファイバーの径は $0.1 \sim 1 \mu \mathrm{m}$, コイル長さは反応時間に依存して 0.1 ～ $10 \mathrm{~mm}$ である。反応条件を制御することにより, コイル径 が大きな $(20 \sim 50 \mu \mathrm{m} \Phi)$ コイルやファイバー径が非常に小さな コイル $(50 \sim 200 \mathrm{~nm})$ が得られる。このようなコイルは, 非常に弾 力性に富んでいる (超弾力性コイル)。コイルの伸び率は通常の CMCでは $1.5 〜 3$ 倍であるが, 超弾力性 CMCでは 10～15 倍に達 し, また完全弾性的な伸縮が可能である。さらに $\mathrm{mg}$ オーダーの 微小荷重でも容易に伸長し, 荷重と伸びとの間にはほぼ直線関係 が認められる。触媒の種類 $(\mathrm{Fe}-\mathrm{Ni}, \mathrm{Pd} / \mathrm{Pt}$ など) と反応条件の制 御により, タンパク質と同様な一重らせん状 (シングル) コイル のみを大量に合成することもできる。Fig.2に, Fe-Ni系触媒を用 いて得られたシングルコイルとその拡大写真を示す。シングル コイルの含有率はほぼ $100 \%$ である。多くのシングルコイルの表 面には, ひれ状の析出物や筋状の凹みがファイバー軸方向に沿っ て観察される。

平均粒径がnmオーダーの触媒あるいはセラミック粉末担持微 細触媒を用いると, コイル径が数百〜数十 $\mathrm{nm}$ のナノコイル (CNC) が得られる。CNCは,一般にファイバーが一方向に連続してねじ

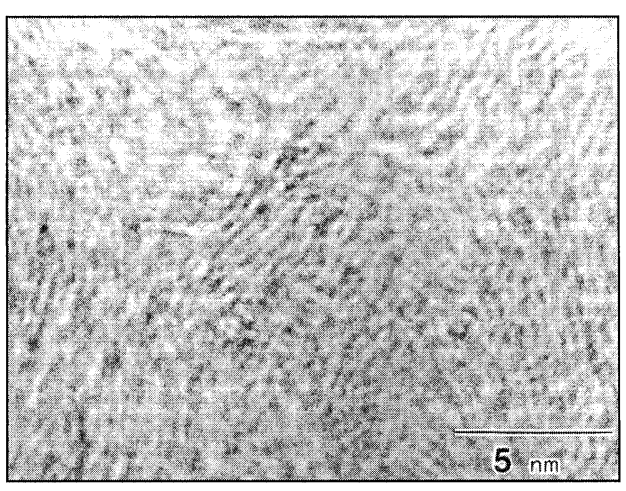

Fig.3 High-resolution TEM image of as-grown CMCs.

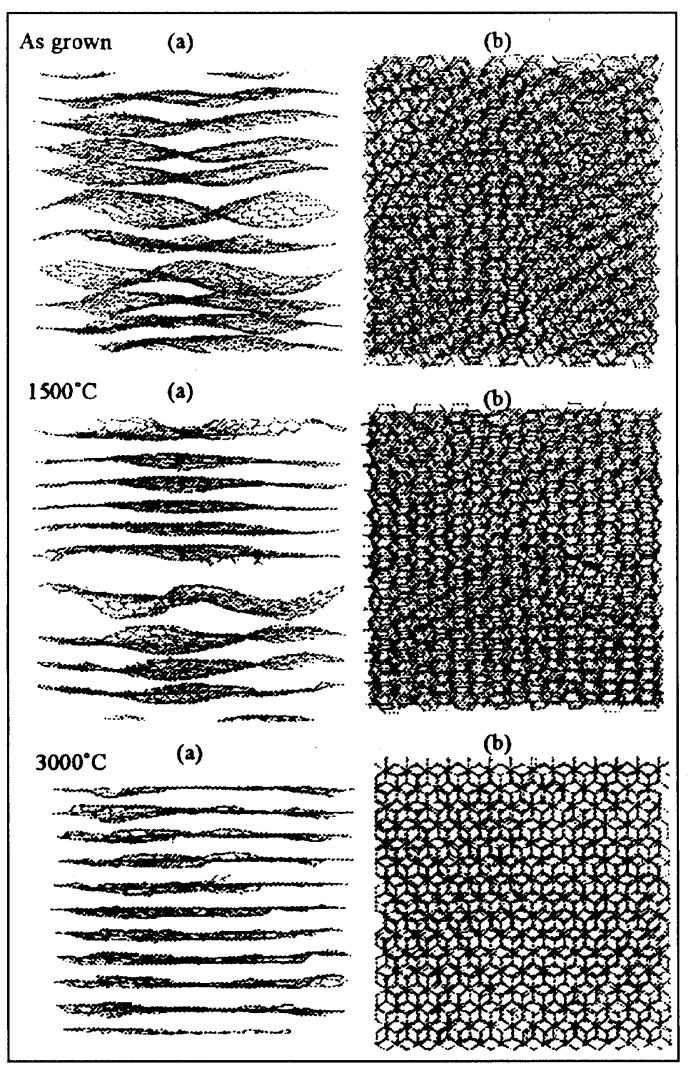

Fig.4 Neutron diffraction analysis. A side-(a) and surface-on view (b) of the graphite sheets for the as-grown CMC and the heat-treated CMC at 1500 and $3000{ }^{\circ} \mathrm{C}$.

れた形のシングルツイスト状コイルである。CMCでは巻き方向 は途中で変化しないが, CNCではしばしば巻き方向が変化する場 合か観察される。As-grown CMCの破断面の形状は, 一方が凹状で あれば他方は必ず凸状であり，両者が必ずペアーとなっている。

\section{3 微細構造}

As-grown CMCは, ほとんど非晶質の活性炭と類似のXRD パ ターンを示す. Fig.3にas-grown CMCのTEM像を示す。グラフ アイト層の短距離秩序は認められるが, その積層数はせいぜい 10 層, 層間距離は約 $5 \mathrm{~nm}$ で, 三次元的に完全にランダムな方向に 向いている。さらに, 電子線回折, 中性子線回折およびラマンスペ クトルの解析結果からも, as-grown CMCはほとんど非晶質である 


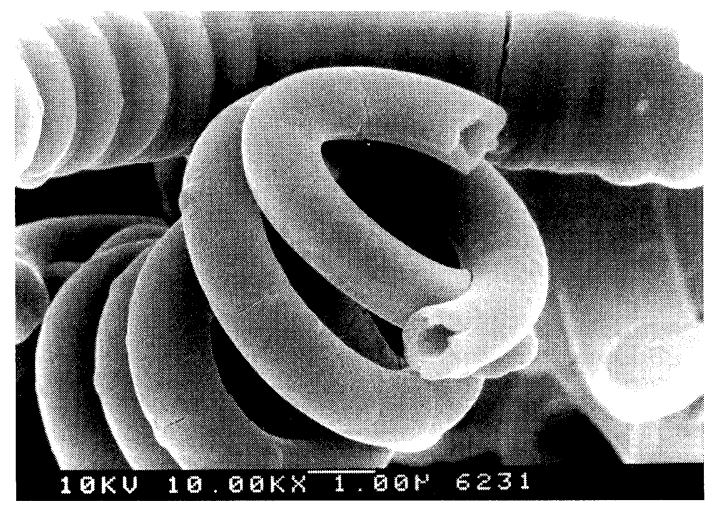

Fig.5 Coiled $\mathrm{TiO}_{2}$ microtube obtained by a CVD coating of $\mathrm{TiO}_{2}$ layers on CMC-template.

と考えられる。しかし，高温（特に $2500{ }^{\circ} \mathrm{C}$ 以上) で熱処理すると 次第にグラファイト化し，これがヘリングボーン (ニシンの骨状) 構造状に発達する。コイル形態は, 熱処理・グラファイト化して もほとんど変化しないが, 多少もろくなる傾向が認められる。Asgrown 拉よび熱処理 CMCの中性子線回折スペクトル解析結果を Fig.4 に示す。グラファイト面は, 触媒結晶粒の結晶面に並行に 発達している。触媒粒子 (単結晶) からの炭素粒の析出速度は一 定ではなく, 周期的に速い〜遅いを繰り返す。析出速度が遅いと きに析出した結晶粒は結晶面に並行にゆるく配列した乱層構造 のグラファイト層が形成され, これが熱処理により発達して全体と してグラファイト構造が結晶面に平行に発達するものと考えら れる。すなわち, CMC は熱処理条件を制御することにより, 非結 晶質から結晶質まで任意の微細構造をもつコイルが得られるこ とがわかる。これはCMCの大きな特徴の1つである。

\section{4 セラミックスマイクロコイル・マイクロチューブの合成}

$\mathrm{CMC}$ は高温で気相拡散処理すると, 種々のセラミックスマイ クロコイル/マイクロチューブが得られる。その際, CMCのコイ ル形態は完全に保持されている。例えば, $\mathrm{CMC}$ を $\mathrm{TiCl}_{4}+\mathrm{H}_{2}$ 雾囲 気中 $800 \sim 1200{ }^{\circ} \mathrm{C}$ で処理すると, CMCの表面から次第に $\mathrm{TiC}$ 化 され, 最終的にすべての炭素が TiCに変化して TiCマイクロコイ ル /チューブが得られる。CMCを $\mathrm{TiCl}_{4}+\mathrm{H}_{2}+\mathrm{N}_{2}$ (あるいは $\mathrm{NH}_{3}$ ) 雲囲気中で処理すると TiN コイルが得られる。またTi $\left(\mathrm{OC}_{3} \mathrm{H}_{7}\right)_{4}+$

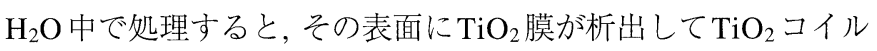
が得られる(Fig.5)。

\section{3. 物性・特性}

$\mathrm{CMC}$ の特長は, その特異的な3D-へリカル／らせん構造はもち ろんであるが, ファイバーの中心部にはナノチューブのような空 洞は存在せず，中心部まで微細な炭素粒で完全に詰まっている。 また, 非晶質で比表面積が大きい $\left(100 \sim 140 \mathrm{~m}^{2} / \mathrm{g}\right)$ 点も大きな特 徵である。また, 3D-ヘリカル／らせん構造をもっているので, 弾力性が非常に優れており, 微小な加重下でも元のコイル長さの $10 \sim 15$ 倍まで伸長し, 元の長さに完全に戻る。As-grown CMC のスプリング定数は $2.6 \times 10^{-2} \mathrm{~N} / \mathrm{mm}^{2}, 1500^{\circ} \mathrm{C} て ゙$ 熱処理したCMC では $3.4 \times 10^{-2} \mathrm{~N} / \mathrm{mm}^{2}$ である。

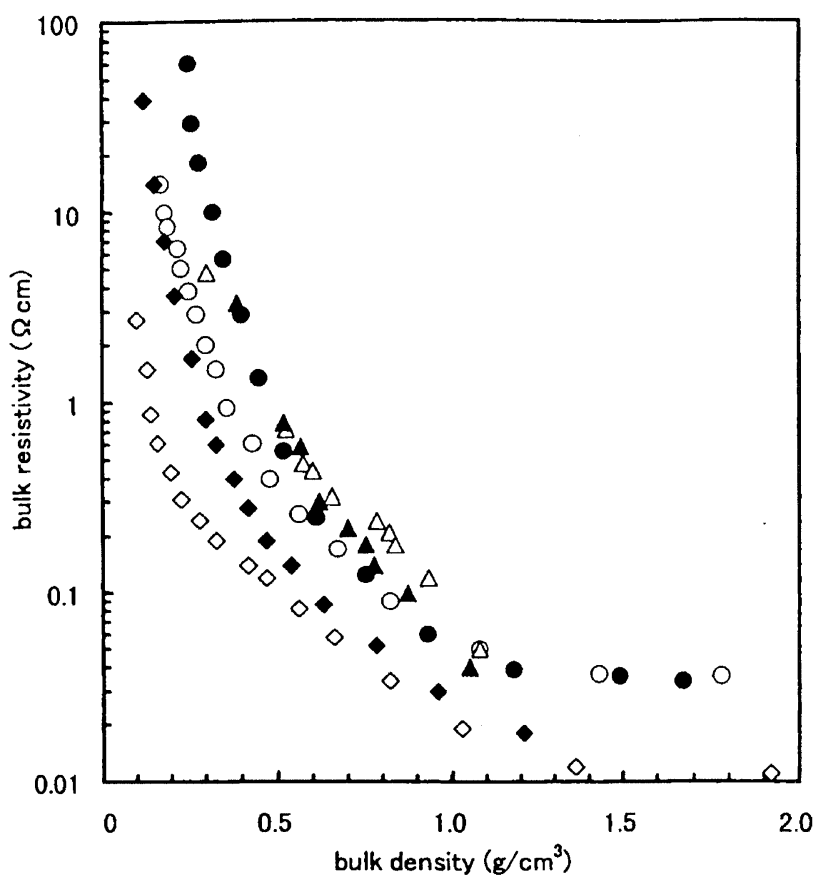

Fig.6 Bulk electrical resistivity obtained at room temperature in air. $(\Delta)$ graphite coils (coil length $>1 \mathrm{~mm}),(\boldsymbol{\Delta})$ graphite coils (coil length $<1 \mathrm{~mm}$ ), $(\bigcirc)$ as-grown carbon coils (coil length $>1 \mathrm{~mm}$ ), (O) as-grown carbon coils (coil length $<1 \mathrm{~mm}),(\diamond) \operatorname{VFGCF}(1)$, and $(\diamond) \operatorname{VGCF}(2)$.

Fig.6にバルク (粉末) 状の as-grown および熱処理CMC の電気 抵抗值を示す。As-grown CMCのバルク (粉末) 電気抵抗值は, かさ密度に依存し,かさ密度が $0.2 \mathrm{~g} / \mathrm{cm}^{3}$ では $10 \Omega \mathrm{cm}, 1 \mathrm{~g} / \mathrm{cm}^{3}$ では $0.1 \Omega \mathrm{cm}$ 以下である。これらの值は気相成長炭素繊維 (VGCF) およびグラファイトコイルなどの值とほほ同じオーダーである。 熱処理しても電気抵抗值はそれほど低くはならない。これはグ ラファイト層がヘリングボーン構造をとるためと考えられる。単 線コイルの電気抵抗は $0.01 \sim 0.001 \Omega \mathrm{cm}$ である。単線コイルには $40 \sim 80 \mathrm{~V}$ で $0.4 \sim 0.5 \mathrm{~mA}$ 程度電流を流すことができるが, それ 以上では発熱して断線する。As-grown CMC は, 電気抵抗が温度 上昇とともに単調に低下する半導体的性質を示す10),11)。例えば, 長さ $2.0 \mathrm{~mm}$ のコイルでは, $100 \mathrm{~K} て ゙ 13.3 \mathrm{k} \Omega, 270 \mathrm{~K}$ では $11.6 \mathrm{k} \Omega$, $400 \mathrm{~K}$ では $11.2 \mathrm{k} \Omega$ であり, 弱い温度依存性を示す。熱活性型や ホッピング伝導などに基づく電導度のいろいろな温度 $(\mathrm{T})$ 依存 性をプロットすると, $\ln \mathrm{T}^{1 / 2} \sigma$ 対 $\mathrm{T}^{-1 / 4}$ のプロットが最もよく合い, 三次元のバリアブルレンジホッピングであると考えられる。200〜 $300 \mathrm{~K}$ における電導度の温度依存性から活性化エネルギーを求め ると約 $4 \mathrm{mV}$ である。この活性化エネルギーはキャリアーの生成で はなく, ホッピング移動に起因すると考えられる。As-grown CMC は半導体的性質を示すが, 熱処理すると電気抵抗の温度依存性は 小さくなり, $3000{ }^{\circ} \mathrm{C}$ 熱処理すると $0 \sim 300{ }^{\circ} \mathrm{C}$ の間では電気抵抗は ほとんど変化しなくなる。

CMC は荷重を印加すると伸び, 荷重を除去すると収縮するが, 両者の間には良い相関関係が認められる。コイルの伸縮に伴い CMCの電気パラメータは敏感に変化する。例えば, Fig.7にas- 


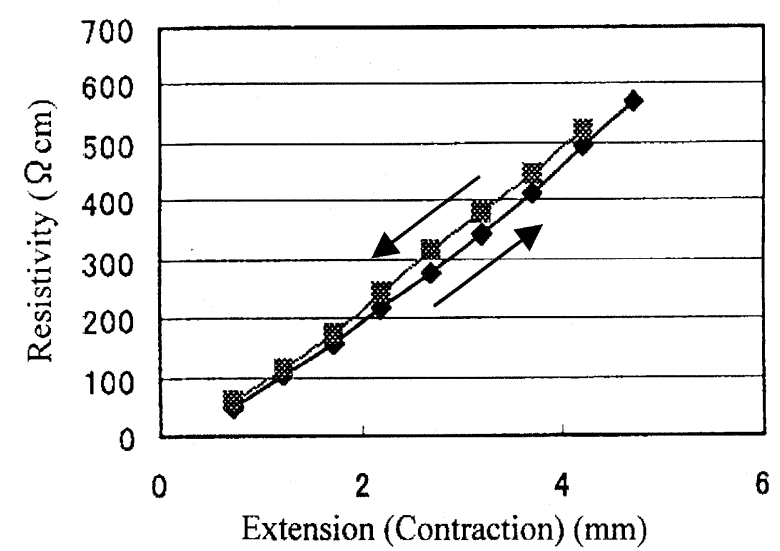

Fig.7 Effect of an extended length on an electrical resistivity.

Applied direct current
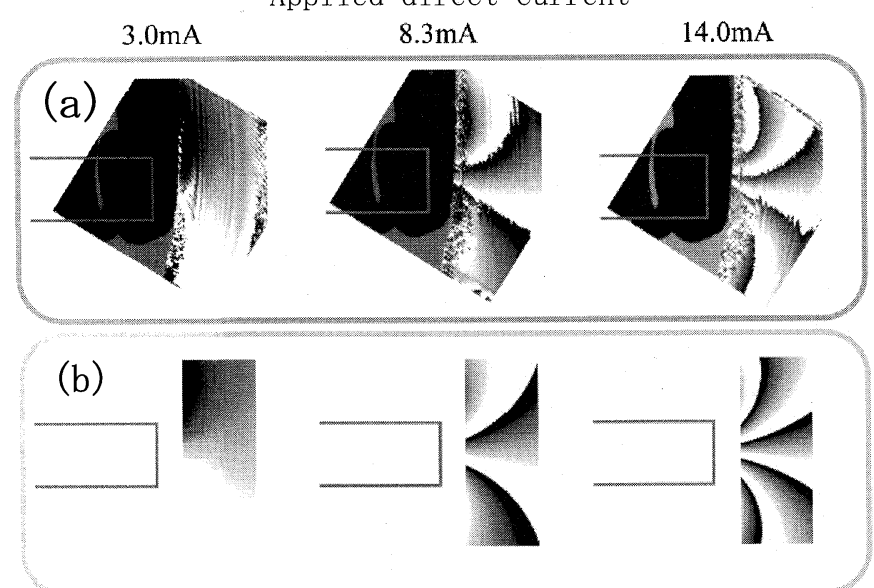

Fig.8 Holograms taken at a cross section of CMC. a) Experimental, (b) theoretical.

grown CMC を伸縮させた際の電気抵抗変化を示す。電気抵抗は 伸長させると大きくなり, 逆に収縮させると小さくなる。ほかの電 気パラメー夕も伸縮させると再現性良く変化する。これは伸縮 に伴うファイバーの内部応力変化, コイル径やピッチの変化, 一 定のコイル長さでのコイルの巻き数変化などが影響しているもの と考えられる。

高温で熱処理したコイルを, 強磁場 (最大 $12 \mathrm{~T}$ ) 中で磁束方向 に並行または垂直にセットし, 室温下でコイルに $1 \mu \mathrm{A}$ のC電流 を流しながら磁気抵抗変化を検討した7)。熱処理していないコイ ルはほとんど磁気抵抗変化を示さないが, $1500 〜 2000{ }^{\circ} \mathrm{C}$ で熱処 理して得られたコイルは負の抵抗変化 (すなわち抵抗值の減少) を示し, $2500{ }^{\circ} \mathrm{C}$ 以上では逆に大きな正の抵抗変化を示す。特に $3000{ }^{\circ} \mathrm{C}$ 以上で, コイル軸を磁束方向に平行にセットした場合は, $12 \mathrm{~T}$ で $40 \%$ の著しい磁気抵抗変化を示す。

CMC はソレノイド状構造をしているので, ファラデイの電磁 誘導の法則に従い効率良く電磁波を吸収し, 誘導起電力を発生す る。誘導起電力は, 周波数が高いほど, またコイルが長いほど, 大 きくなる12)。この誘導起電力の発生に伴うへリカル状誘導電流 よりコイル端には微弱な磁場が発生する。山本ら 13)は, FIB を用

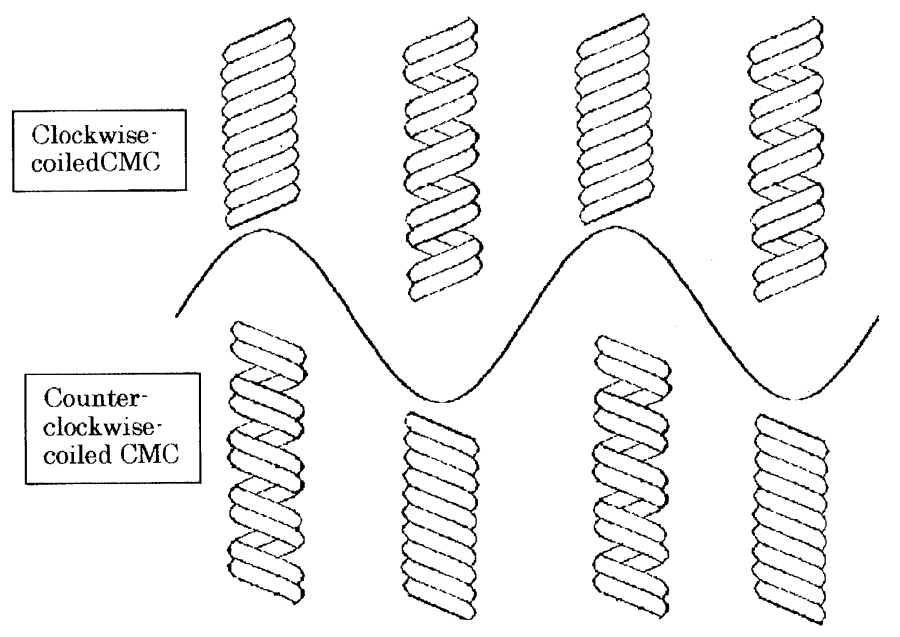

Fig.9 Schematic illustration of the expansion and contraction motions of chiral CMC.

いて単線コイル (コイル径： $4.4 \mu \mathrm{m}$, ピッチ： $2.1 \mu \mathrm{m}$ )の雨端に 電極を付け,これに $3 \sim 13 \mathrm{~mA}$ の電流を流しながら得た走査イオ ン顕微鏡像と, 電子線ホログラフィーで計測した電子波の位相像 を比較検討した。その結果, 両者は非常によく一致しており, ホ ログラフィーを用いるとCMCの端面に発生する微弱磁場の可視 化が可能であることを見出した $\left(\right.$ Fig.8)。津田ら ${ }^{14)}$ は, コイルに 交番電流を流すとコイルが伸縮し, その伸縮挙動は右巻きコイル と左捲きコイルでは逆であることを見出した。Fig.9に交番電流 に伴うコイルの伸縮挙動を示す。

\section{4. 応用}

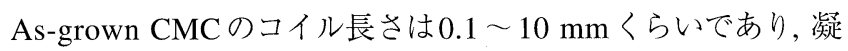
集している。応用に際しては高速粉砕機で粉砕後分級し, コイル 長さ50〜 $1000 \mu \mathrm{m}$ の粉末状として用いるが, そのままでは取り 扱いが不便であるので一般に樹脂中に複合化させて用いる。樹 脂としてはポリウレタン (PU), ポリメチルメタクリレート (PMMA)，シリコーン樹脂などが用いられる。

\section{1 強化材}

PAN 系炭素繊維やVGCFのような直線状ファイバーを樹脂複合 材の強化繊維として用いた場合, しばしばマトリックス樹脂からフ アイバーの引き抜け現象が起こり, 有効に強化されない。特に変 形量の大きな弾力性樹脂に対する有効な強化材はない。CMC は コイル状をしているので弾力性があり, 弾力性樹脂中に複合化さ せると, 樹脂と一緒に伸縮して引き抜けが起こりにくく繊維強化 材として有効と考えられる。そこで, ヤング率の小さなエポキシ 樹脂に対する CMCの強化効果を検討した15)。ヤング率が $1.2 \mathrm{MPa}$ のエポキシ樹脂中にCMCを $3 \mathrm{wt}$ \% 添加した複合材の s-s 曲線を Fig.10に示す。ヤング率はマトリックス樹脂の約 1.8 倍 (PANフ アイバーでは約 1.2 倍) に, また引つ張り強度は約 2.3 倍 (PAN フ アイバーでは約 1.6 倍) 向上した。

\section{2 電磁波吸収}

種々のコイル長さの CMCを, 種々の割合 (添加量)で PU, PMMA, およびシリコーン樹脂中に分散・複合化させて得られた 


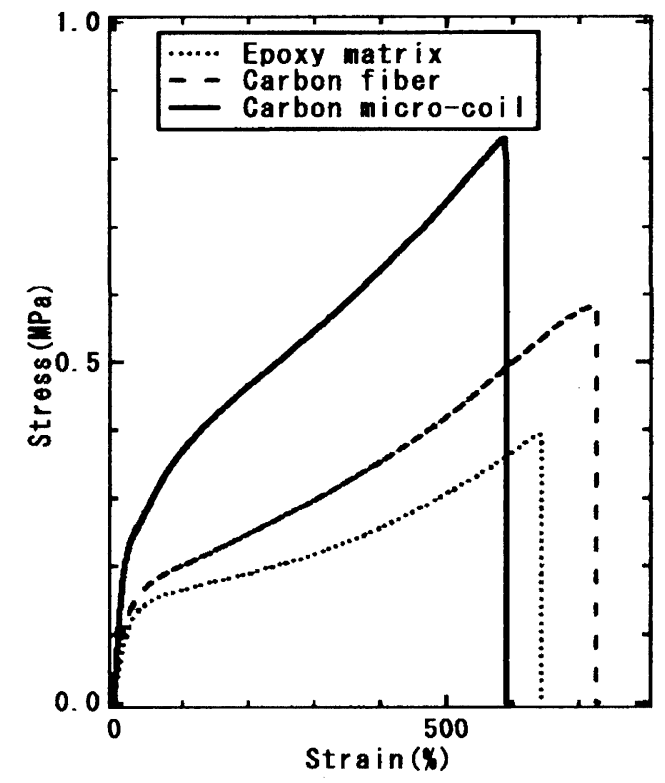

Fig.10 Stress-strain curves of CMC (3 wt \%) /epoxy composite sheet. Young modulus of epoxy matrix : 1.2 MPa.

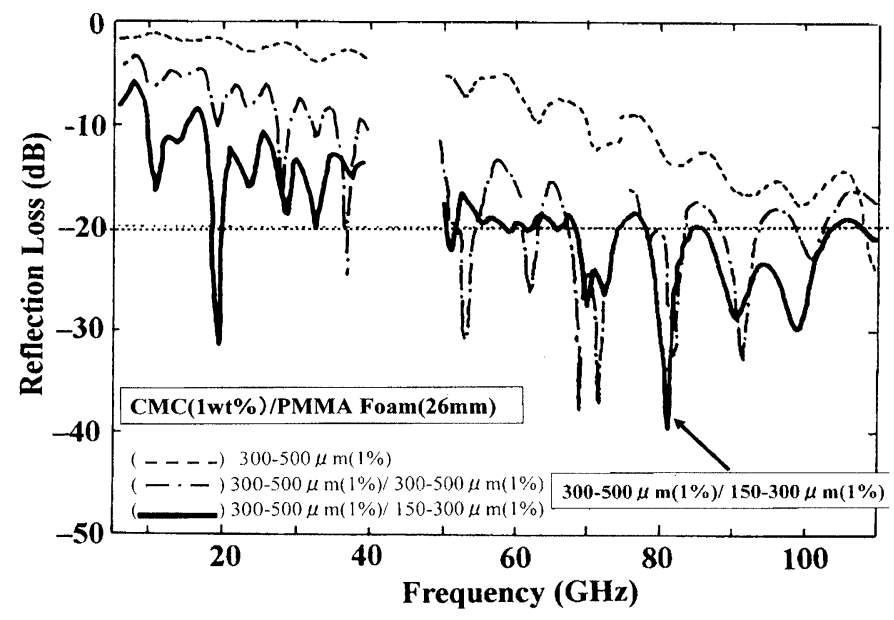

Fig.11 Reflection loss of CMC (1 wt \%)/PMMA foam.

ビーズ (直径：0.2 1 mm) および発泡板 (厚さ：13〜26 mm) の2種類のサンプルについて, 10〜 $110 \mathrm{GHz}$ 帯域での電磁波吸 収率を自由空間法で測定した5)，16)。CMC/PMMA ビーズでは， CMCを 1〜2 wt \%添加したサンプルにおいて, 実用的目標值であ る-20 dB (吸収率 $99 \%$ ) 以上の值が特定周波数領域で達成できる ことがわかった。吸収率は, 添加量がこれより少なくても多すぎ ても低下する。Fig.11にCMC/PMMA発泡体の電磁波吸収特性を 示す。単層サンプル (厚さ：26 mm) ではあまり電磁波を吸収し ないが, 300〜 $500 \mu \mathrm{m}(1 \%) / 150 〜 300 \mu \mathrm{m}(1 \%)$ の二層サンプル (全厚：26 mm) では, $50 \sim 110 \mathrm{GHz}$ の幅広い周波数領域にわたっ て, $-20 \mathrm{~dB}$ 以上のきわめて優れた吸収特性を示すことがわかる。

\section{3 マイクロ波発熱17)}

CMCにより吸収された電磁波のエネルギーは, 誘導電流とな り, CMCには電気抵抗があるのでジュール熱を発生して最終的 に熱エネルギーとして消費される。例えば, CMCを電子レンジ $(2.45 \mathrm{GHz})$ 中に入れると, 電磁波を吸収して短時間で赤熱・酸

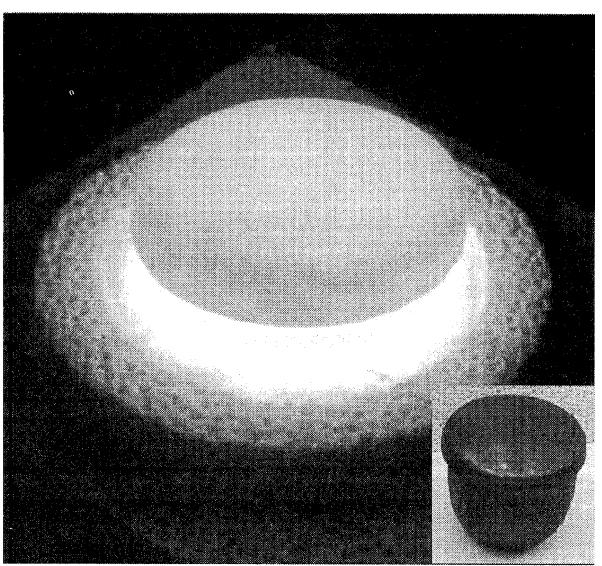

Fig.12 CMC-Crucible heated in microwave oven. Heating time : $10 \mathrm{~min}$.

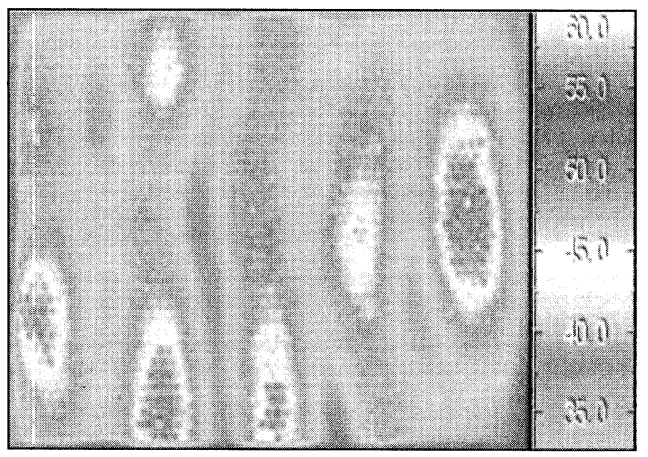

Fig.13 IR thermograph of the visualization element after heating by microwave oven.

化・燃焼・消失する。シリコーンオイル中に $1 \mathrm{wt} \%$ 添加したサ ンプルの温度上昇率は, $\mathrm{CMC}$ の場合, 水, 炭素粉末, 炭素繊維など の場合より $3 \sim 5$ 倍高く, 15 秒加熱では $120 \sim 150{ }^{\circ} \mathrm{C}$ となり, エネ ルギー変換効率も 60 ～70 \%に達する。また, CMCをセラミック ス中に添加した電子レンジルツボは, 電子レンジで10分間加熱す ると $800 〜 1000{ }^{\circ} \mathrm{C}$ ま温度上昇する $($ Fig.12)。

\section{4 電波の可視化材}

電波は目に見えないため, どこから発生しそれがどの程度の強度 であるのかがわからないので, 電波の可視化技術の開発が求められ ている。CMCはマイクロ波を効率良く吸収しこれを熱に変換す るので, この熱を赤外線サーモグラフで読み取れば, 電波を可視 化できる。Fig.13は, CMCビーズを充填した可視化板を電子レ ンジ中央部に垂直に入れて 5 秒間加熱した後の赤外線サーモグラ フである。 $6 \mathrm{~cm}$ おきに昇温部分が認められ, 電子レンジ中のマイ クロ波の様子が容易に目視できる。可視化板を移動すれば三次 元的なマイクロ波の空間分布が簡単に短時間で求められる。

\section{5 細胞増殖・抑制}

自然界には微弱な交番電磁波が飛び交っており，CMCはこれ らを吸収して 微弱な誘導電流を発生し, これに伴い微弱な静磁場 を発生していると考えられる。この微弱静磁場は, 生体細胞の増 殖や代謝活性化作用などに影響を及ぼすことが考えられる。小 川18）は, 皮膚の表皮にある繊維芽細胞 (タイプIコラーゲン mRNA) 


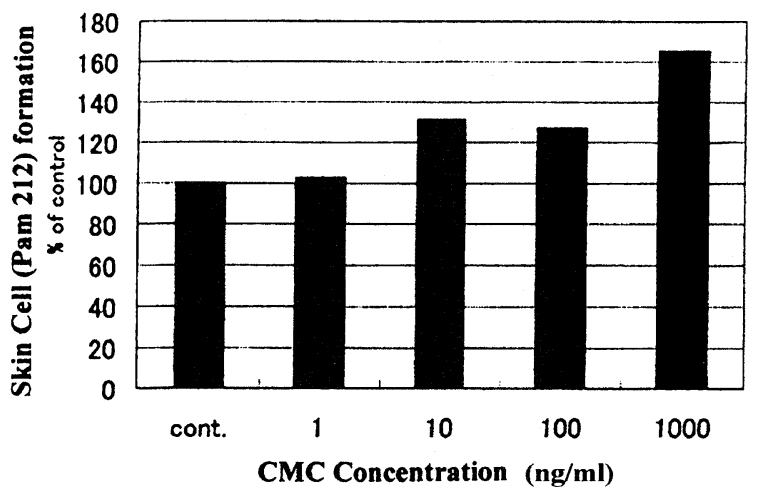

Fig.14 Breading effect of CMC on the skin cell (Pam 212).

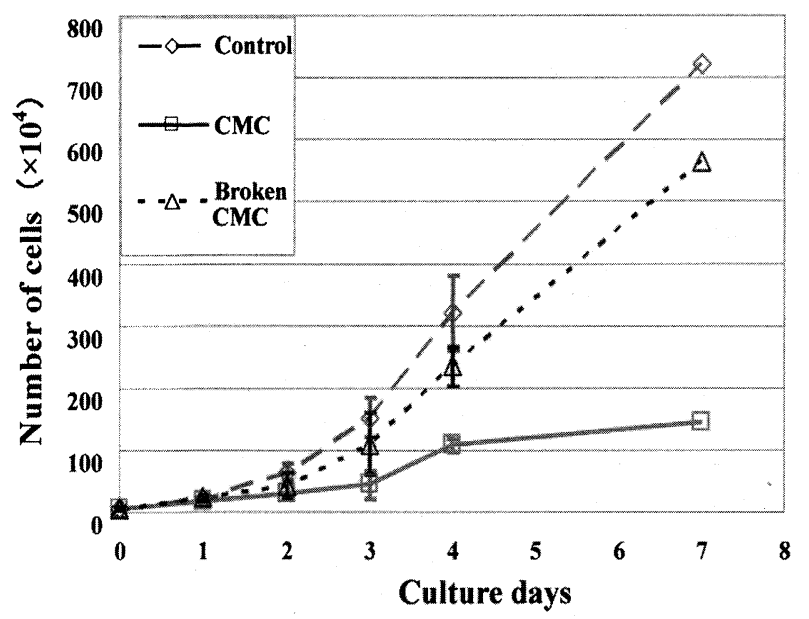

Fig.15 Effect of culture days on the number of cancer cell (Hela cells).

にCMCを加えて培養すると,その発現量は約 10 \% 増加することを 見出した。さらに, 表皮細胞 (マウスケラチノサイト由来Pam 212 細胞)にCMCを加えて培養すると細胞数が 60 \% 増加し, 表皮の 新陳代謝が活性化されることも見出した (Fig.14)。これらの活 性化効果を利用して, CMC の実用化第 1 号として, CMCを添加 した化粧品が実用化されている18)。一方，ケロイドの原因となる 緎維芽細胞やガン細胞に対しては著しい抑制効果を示す。例え ば, 繊維芽細胞であるマウス結合組織由来のL細胞にCMCを添 加して培養すると, 10 日後の細胞数は添加しない場合の $1 / 20$, CMC を完全に粉砕したCMC粉末の場合は1/2であった。Fig.15 にヒト子宮䅡部ガン由来の Hela 細胞の増殖に及ぼす CMC 添加 効果 $(\mathrm{CMC} ： 0.04 \mathrm{wt} \%)$ を示す。7日間培養後のがん細胞数は, CMCを添加すると添加しない場合の $19 \%$ ，CMCを完全に粉砕し てコイル形状をなくしたものでは $76 \%$ \%゙あった。一方, 活性炭で は逆に増加した。すなわち, CMCはがん細胞由来株の増殖を著 しく抑制する効果があることがわかる。CMCのこのような細胞 の種類に依存した特異効果の理由は, 現在のところ明らかではな い。粉末状CMCでは抑止効果が小さいので, CMCのがん細胞増 殖抑制効果は, CMCの炭素質そのもののもたらす効果というょ り, CMCのマイクロコイル状という特異形態のもたらす効果で あると考えられる。

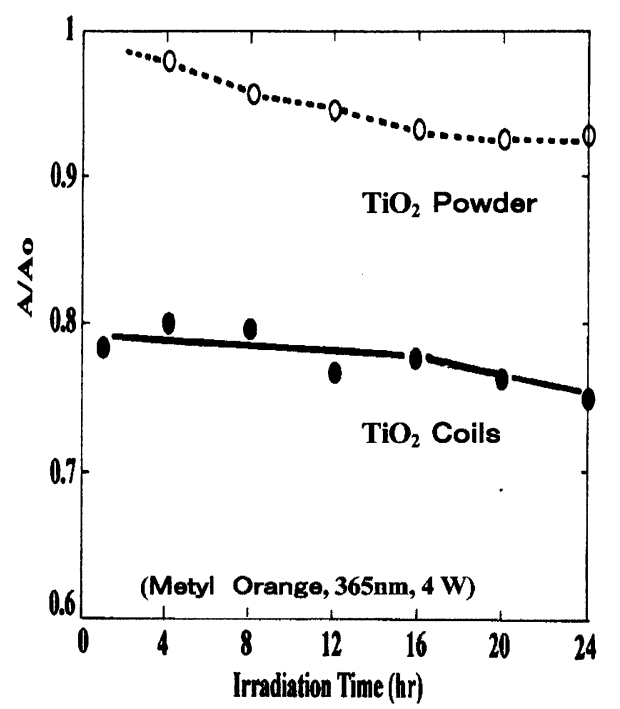

Fig.16 Photo-catalytic effect of $\mathrm{TiO}_{2}$ microcoils measured by Methyl Orange process. A : Absorptance of visible rays under irradiation of UV ray $(365 \mathrm{~nm})$, Ao : absorptance of visible rays without irradiation of UV ray.

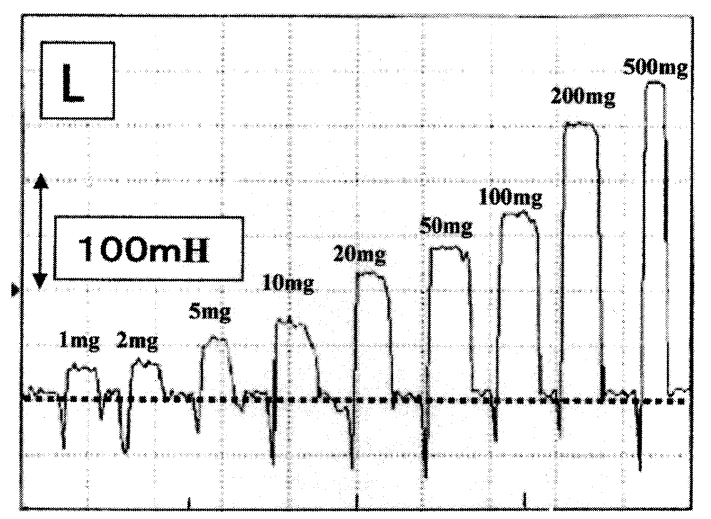

Fig.17 Change in L (inductance) parameter of CMC (1 wt \%) / polysilocone thin sensor tactile element under applied loads. Thickness of element : $0.1 \mathrm{~mm}$.

\section{6 光触媒効果}

Fig.16に, $\mathrm{TiO}_{2}$ マイクロコイル (Fig.5) とこれを完全に粉末に した $\mathrm{TiO}_{2}$ 粉末の紫外線 $(365 \mathrm{~nm}, 4 \mathrm{~W})$ 照射下でのメチルオレンジ の光分解率を比較した。明らかに $\mathrm{TiO}_{2}$ コイルのほうが高い光触 媒活性を示すことがわかる。コイル形状のもたらす効果である。

\section{7 触覚・近接センサ素子}

$\mathrm{CMC}$ を弾力性樹脂中に添加・複合化させた素子 (以下, $\mathrm{CMC}$ センサ素子と略す)は, 種々の刺激を高感度で識別・検出できる 優れた触覚センサ特性があることが見出された5),19)。CMCはす でに述べように, 微小の応力により伸縮しその際電気抵抗 $(\mathrm{R})$ な どのさまざまな電気パラメータが変化する。Fig.17に, CMCを 弾力性シリコーン樹脂中に $1 \mathrm{wt} \%$ 添加したセンサ素子 (厚さ： $1 \mathrm{~mm}$ )に, 微小荷重を印加した際のL (インダクタンス) 成分の 変化を示す。 $1 \mathrm{mgf}$ の荷重でも明らかな変化が認められる。この 值は圧力換算で $1 \mathrm{~Pa}$ に相当し人間の皮虚よりも高感度である。 Fig.18に, CMC センサ素子に手を近づけた際のL成分の変化を 


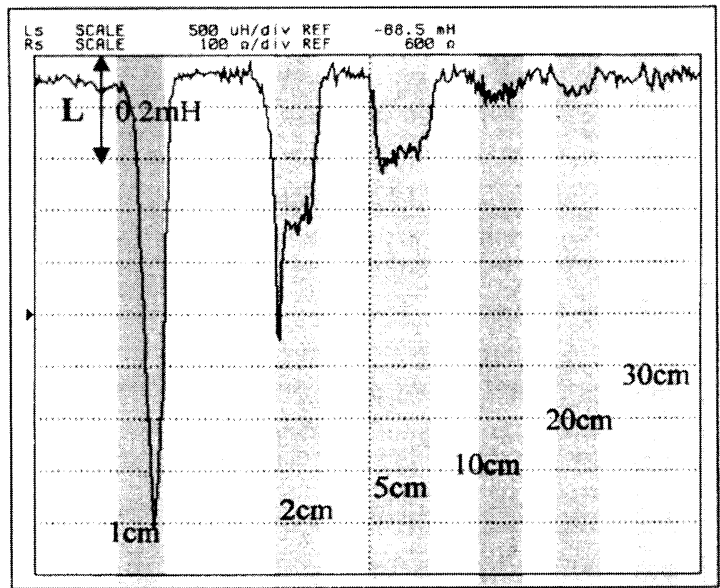

Fig.18 Change in L (inductance) parameter of $\mathrm{CMC}$ /polysilicone tactile sensor element without coming a hand directly into contact with it.

示す。 $\mathrm{CMC}$ に手を $30 \mathrm{~cm}$ 以下に近づけるとL成分の変化が観察 され始め, 近づくにつれて急激に大きくなり (近接信号), 手がセ ンサ素子に接触するときわめて大きな変化 (触覚信号) が観察さ れる。すなわち, CMCセンサ素子は, 高感度の触覚センサとして ばかりでなく近接センサとしても応用できる。

\section{8 電子線エミッター}

中山ら 20)は, CMCの電子線エミッター特性を検討した。電極 間の間隔が $130 \mu \mathrm{m} て ゙ は, ~ 150 \mathrm{~V}$ の非常に低い電圧で電子線の放 出が始まり, $300 \mathrm{~V} て ゙ は 1 \mu \mathrm{A}$ の電流発生が観察された。これはナ ノチューブ製エミッターに匹敵し, 寿命も非常に長いので, エミ ッターとしての応用が期待できる。

\section{9 水素吸蔵材}

$\mathrm{CMC}$ は, 液体窒素温度で, 比表面積が $2000 \mathrm{~m}^{2} / \mathrm{g}$ の活性炭やナノ チューブの 4～5 倍水素を吸蔵する。また構造制御したCMCで は, 室温・高圧下では約 $2 \mathrm{wt} \%$ の水素を吸蔵する 21$), 22) 。 C M C$ は非晶質から結晶質まで任意の構造が制御できるので, 水素吸蔵 材としての応用が期待できる。

\subsection{0 その他}

$\mathrm{CMC}$ はその他, 高度指向性・高感度微小アンテナ, 弾力性樹 脂用強化特性など, 多くの優れた特性があり, 非常に幅広い分野 での実用化が期待されている。

\section{5. むすび}

カーボンマイクロコイル $(\mathrm{CMC})$ は, コイル径がミクロン〜ナ
ノオーダーで, 森羅万象の基本構造とも言える3D-ヘリカル/ら せん構造をしており，さらに非結晶～結晶質の微細構造をもち， 既存材料には得られないような多くの優れた特性を有している。 したがって, 新規高度機能性材料として, 電磁波吸収材 (特に $\mathrm{GHz}$ 領域), 触覚センサ, 生物活性化触媒, エミッター, キャパシター など, 幅広い応用が期待できる。

\section{6. 謝辞}

本研究の一部は, 文部科学省知的クラスター創成事業「ロボテ イック先端医療クラスター」として行われた。

\section{文 献}

1) S. Motojima, S. Ueno, T. Hattori and H. Iwanaga, Appl. Phys. Lett. 54 (1989) 1001-1003.

2) S. Motojima, M. Kawaguchi, K. Nozaki and H. Iwanaga, Appl. Phys. Lett. 56 (4) (1990) 321-323.

3）元島栖二, 川口雅之, 岩永＼cjkstart浩, TANSO 1992 [No.151] 41-50.

4）元島栖二, 岩永 浩, TANSO 1996 [No.174] 215-224.

5）特集「ナノヘリカル・らせん構造物質・材料」, マテリアルインテグ レーション 17 (7) (2004), 18 (8) (2004).

6) 元島栖二, 応用物理, 73 (10) (2004) 1324-1327.

7) S. Motojima, Y. Hishikawa and H. Iwanaga, Recent Develop. Mater. Sci. 3 (2002) 633-662.

8) S. Motojima and X. Chen, Encylopedia for Nanosci. \& Nanotech. 6 (2004) 775-794.

9) 陳 秀琴, 元島栖二, 化学工業 1 月号 (2007) pp.27-32.

10）金藤敬一, 鶴田 信, 元島栖二, 電学論 A 118 (12) (1998) 1425-1428.

11) M. Fujii, M. Matsui, S. Motojima and Y. Hishikawa, Thin Solid Films 409 (2002) 78-81.

12) Y. Kato, N. Adati, T. Okuyama, T. Yoshida, S. Motojima and T. Tsuda, Jpn. J. Appl. Phys. 42 (2003) 5035-5037.

13) K. Yamamoto, T. Hirauyama, M. Kusunoki, S. Yang and S. Motojima, Ultramicroscopy 106 (4-5) (2006) 314-319.

14) T. Kojima, T. Tsuda, Y. Kato and S. Motojima, Jpn. J. Appl. Phys. 45 (4A) (2006) 2695-2698.

15) K. Yoshimura, K. Nakano, T. Miyake, Y. Hishikawa and S. Motojima, Carbon 44 (2006) 2833-2838.

16）元島栖二, “次世代電磁波吸収体の技術と応用展開” (2003) pp.166188 , シーエムシー出版.

17）窪寺俊也, 河辺憲次, 元島栖二, 検査技術 11 (10)（2006）55-58.

18）小川雅久, Fragrance J. 1 (2004) 58.

19）元島栖二, 河辺憲次, セラミックス 40 (2) (2005) 111-114.

20) L. Pan, T. Hayashida, M. Zhang and Y. Nakayama, Jpn. J. Appl. Phys. 40 (2001) 235

21) Y. Furuya, T. Hashishin, H. Iwanaga, S. Motojima and Y. Hishikawa, Carbon 42 (2004) 331-335.

22）古谷吉男, 元島栖二,ケミカルエンジニアリング 48 (12) (2003) 49-55. 